Medisin og kunst

\title{
Kvinne med bok
}

\section{Lesing er uløselig knyttet til medisinfaget. Noen ganger kan det bli for mye av det gode, som ved innspurten i en eksamensperiode. Til andre tider kan vi ønske oss mer tid til faglig fordypning i en bok.}

Helt fra før Gutenbergs tid har lesende mennesker vært et vanlig motiv i bildekunsten. Tidligere var det et poeng å vise hvilke ord som ble lest, men det ble snart av større interesse for kunstnere å vise selve lesesituasjonen (1). Variasjonsmulighetene er mange. Noen lesere er oppslukt av teksten, mens andre lar sine tanker vandre selv med en oppslått bok i hendene.

Det lesende menneske i bildekunsten er oftest en ung kvinne, men vi finner også barn og gamle. Noen sitter sammen og leser i samme bok. I andre situasjoner vises en scene med høytlesning. Kunstnere har eksperimentert med lyssetting, som for eksempel fra en enkelt lampe eller fra et vindu. Personen som leser vil oftest sitte, men kan også godt ligge i en seng eller på en sofa.

Pablo Picasso (1881-1973), som malte over femti bilder av lesende mennesker, eksperimenterte med tidsdimensjonen i mange bilder der motivet er en liggende kvinne som leser i en bok. Vi ser ansiktet fra mer enn én synsvinkel samtidig. Modellen kan ses i profil, men det øyet som da normalt ikke kan ses, er trukket frem som når man vender hodet. Det er vel bare ett eksempel fra den levende natur på noe liknende, nemlig det som skjer med mange flyndrearter før de graver seg ned i sandbunnen. Det ene øyet er da vandret over på siden og har tatt plass sammen med det andre. De er ikke skapt asymmetriske.

Det bildet som vises her, ble malt av Picasso i 1932 og har tittel Kvinne med bok. Jeg assosierer det med en lege, kanskje turnuskandidat, som vil finne ut mer om en sykdom eller skade hun nylig har vært konfrontert med på sykehuset. Denne kvinnen har et fokusert blikk, men hun ser ikke på boken. Det er ingen motsetning i dette. Ettertenksomme pauser i lesingen er nødvendige for forståelse av teksten. Fingrene i det løse grepet lager en vifte som perfekt videreføres i den åpne bokens fem sider, en visuell spøk. Det er sent på kvelden. Bak henne til venstre på bildet er det et mørkt vindu. Vinduskarmen ses på samme sted som kanten av et speil i et kjent portrettmaleri av Madame Moitessier malt av Jean-Auguste Ingres (1780-1867).

Picasso har bevisst gitt sin modell den samme holdning og plassering som Ingres gjorde på sitt bilde hundre år før. Men også Picasso har med et speil, prominent plassert som en noe gåtefull refleksjon. Eller er det en røff sketsj av kvinnens hode i en mer fremoverbøyd stilling? Hvordan skal det innrammede speilet tolkes? Kanskje gir det en antydning om hva kvinnen egentlig er opptatt av.

Spådommen om bokens død har ikke slått til. For oppdatering innen spesielle emner er PubMed og andre elektroniske søkemedier av stor betydning. Fagbøkene derimot er nødvendige for forståelse av helheten. Den gode fagbokforfatter kjenner det tematiske landskap og kan vise oss hvordan detaljene henger sammen og påvirker hverandre. Noen forfattere makter ikke dette, og kan føre leseren ut i et faglig tåkelandskap. Jeg håper kvinnen med bok har gjort et godt valg av lesestoff - uansett tema.

\section{Anton Hauge}

anthau@gmail.com

Fysiologisk institut

Universitetet i Oslo

Postboks 1103 Blindern

0317 Oslo

Oppgitte interessekonflikter: Ingen

Litteratur

1. Harding G. The look of reading. Chicago: The University of Chicago Press, 2006.

Manuskriptet ble mottatt 5.9. 2008 og godkjent 7.5. 2009. Medisinsk redaktør Anne Gitte Hertzberg. 
Figur fjernet av hensyn til opphavsrett.

Se artikkelens utgave på internett (html) eller papir for fullstendig versjon.

Tidsskrift for

Den norske legeforening 